Litteratur

1. Rashidi K. Hjerteinfarktpasienter over 80 år bør behandles på samme måte som yngre. Tidsskr Nor Legeforen 2016; 136: 1072

2. Tegn N, Abdelnoor M, Aaberge L et al; After Eighty study investigators. Invasive versus conservative strategy in patients aged 80 years or older with non-ST-elevation myocardial infarction or unstable angina pectoris (After Eighty study): an open-label randomised controlled trial. Lancet 2016; 387: 1057-65.

3. Øie E. Over 80 år og hierteinfarkt. Tidsskr Nor Legeforen 2016: 136: 1058.

4. Psaltis PJ, Nicholls SJ. Management of acute coronary syndrome in the very elderly. Lancet 2016; 387: 1029-30

5. Zwarenstein $\mathrm{M}$, Treweek S. What kind of randomized trials do we need? J Clin Epidemiol 2009: 62: 461-3.

6. Bjerre E, Brasso K, Midtgaard J. Pragmatiske studier er vigtige for medicinsk forskning. Ugeskr Laeger 2015; 177: V10140571.

7. Tegn N, Abdelnoor M, Aaberge $L$ et al. Invasive strategy in acute coronary syn drome - Authors' reply. Lancet 2016; 387: 2504

8. Myhre PL, Laake K, Seljeflot I et al. Klinisk forskning på eldre. Tidsskr Nor Legeforen 2016; 136: 208.

\section{E. Øie svarer:}

Nicolai Tegn og medarbeidere er uenige i mange av mine kommentarer (1) vedrørende deres studie After Eighty. For å gjenta det jeg skrev i lederartikkelen: After Eighty er en godt gjennomført studie som bedre enn noen annen tidligere studie har sett på nytten av tidlig invasiv koronarutredning av de eldste pasientene med akutt koronarsyndrom uten ST-elevasjon. Publisering i The Lancet er imponerende og et kvalitetsstempel. Men jeg tillot meg å kommentere at det var lav prosentandel av den totale pasientpopulasjonen som ble inkludert (11\%). Dette er ikke uvanlig i kliniske intervensjonsstudier og er således ingen kritikk av studiedesignen, men bare en konstatering av begrensningene som foreligger når en skal vurdere overførbarheten av studieresultatene til en klinisk hverdag.

Tegn og medarbeidere skriver at de er interesserte i å høre begrunnelsen for at jeg er bekymret når det gjelder seleksjonen av pasientene. Min bekymring gjelder generaliserbarheten fordi hele $56 \%$ av dem som møtte inklusjonskriteriene ikke ble inkludert pga. såkalte logistiske eller andre uspesifiserte årsaker. Det er en svakhet ved gjennomføringen av studien som kan forklare hvorfor disse gruppene ble så store. Årsakene til at aktuelle pasienter ikke ble inkludert ble først forsøkt registrert ved journalgjennomgang ut ifra diagnosekode etter at oppfølgingsperioden var avsluttet, istedenfor at det ble gjort fortløpende. Det er vanskelig og ofte umulig ut ifra pasientjournal å finne ut hvorfor en pasient ikke ble inkludert i en pågående studie. Når det er en stor gruppe pasienter som har usikre årsaker til at de ikke ble inkludert, øker risikoen for uønsket skjevhet i seleksjonen av pasientene. Det vil være av betydning når vi skal vurdere om de fleste eldre med akutt koronarsyndrom uten ST-elevasjon bør utredes invasivt.

Tegn og medarbeidere er åpenbart mer tilfreds med vinklingen og forståelsen til lederskribentene i The Lancet vedrørende den lave prosentandelen inkluderte. Men disse lederskribentene er vel mer kategoriske enn meg når de skriver at den lave andelen aktuelle pasienter «... also suggest that the results might not be applicable to most octogenarians with NSTEMI and unstabile angina» (2).

Jeg har ikke betvilt at effekten på det primære endepunktet er i favør av invasiv strategi, men ser man på effekten på dødelighet alene var den langt fra signifikant (p-verdi på 0,534).

Kostnadsanalyser er kompliserte. Jeg ble imidlertid bedt av Tidsskriftet om å ha med en kommentar vedrørende helseøkonomi. Derfor gjorde jeg en grov estimering ut ifra de publiserte data, og resultatet ble jo til gunst for invasiv utredning, siden dette hindret om lag 100 liggedøgn i studieperioden, dog til ukjent kostnad.

Når det gjelder min kommentar om at vi har en ganske liberal praksis i Norge med rask koronarutredning av mange eldre pasienter, er dette sett i forhold til tilsvarende praksis for pasienter under 80 år.
Erik Øie (f. 1967) er dr.med., spesialist i indremedisin og i kardiologi og seksjonsoverlege i kardiologi ved Medisinsk avdeling, Diakonhjemmet Sykehus.

Forfatteren var med på å inkludere pasienter til After Eighty-studien.

\section{Litteratur}

1. Øie E. Over 80 år og hjerteinfarkt. Tidsskr Nor Legeforen 2016; 136: 1058.

2. Psaltis PJ, Nicholls SJ. Management of acute coronary syndrome in the very elderly. Lancet 2016; 387: 1029-30.

\section{Re: En kvinne i 70-årene med rask forverring av kognitiv funksjon}

Reiakvam og medarbeidere presenterer en interessant og lærerik kasuistikk om en pasient med raskt innsettende og reversibel kognitiv svikt som sannsynligvis var utløst av alvorlig hypomagnesemi (1). Vi ønsker å supplere med to kommentarer.

For det først skriver forfatterne flere ganger at det ikke var tegn til delirium. Det finner vi svært overraskende. Etter siste oppdatering av diagnosesystemet Diagnostic and Statistic Manual (DSM-5) er diagnosekriteriene for delirium slik: forstyrret oppmerksomhet og bevissthet, akutt start med tendens til fluktuering, ledsagende forstyrret kognisjon, symptomene kan ikke bedre forklares av en annen nevrokognitiv tilstand, f.eks. demens, og underliggende somatisk tilstand, abstinens eller toksisk påvirkning kan påvises (2).

Ved første gangs undersøkelse (i sykehjemmet) er bevissthet og oppmerksomhet ikke beskrevet, men uansett er det få (om noen) andre tilstander enn delirium som gir en så raskt innsettende kognitiv svikt som hos denne pasienten. Ved innleggelsen i sykehus beskrives hun som passiv, likegyldig og fjern i blikket. Hun hadde altså på det tidspunktet en sikker forstyrrelse i oppmerksomhet og bevissthet, og alle de diagnostiske kriteriene for delirium var altså oppfylt. Vi synes det er litt sørgelig at verken forfatterne eller Tidsskriftets fagvurderere eller redaktører øyensynlig er kjent med symptomene på en så alminnelig og alvorlig tilstand (3). Pasienter med delirium skal gjennomgå en rask og grundig somatisk utredning. De vanlige årsakene (som infeksjoner og traumer) diagnostiseres ofte raskt, mens de mange sjeldnere årsakene (som hypomagnesemi) bare oppdages ved en bredere tilnærming.

For det andre var pasienten heldig som kom til et sykehjemsmedisinsk miljø med diagnostisk nysgjerrighet. Likevel tok det over tre uker før diagnosen ble stilt. Delirium er assosiert med økt risiko for demens og langvarige deliriumepisoder er assosiert med større kognitive utfall $(4,5)$. Dette kan meget vel ha ført til at hennes kognitive funksjonsnivå ble varig dårligere enn om diagnosen hadde blitt stilt raskere. Vi frykter at mange pasienter med reversible årsaker til delirium blir langt dårligere utredet enn dette - eller ikke utredet i det hele tatt, og forblir kognitivt svekket resten av livet. Etter vårt syn er det en klar medisinsk feil å legge pasienter med delirium av uavklart årsak inn i demensavdeling i sykehjem. Slike pasienter trenger umiddelbar utredning i sykehus.

\section{Torgeir Bruun Wyller}

t.b.wyller@medisin.uio.no

Leiv Otto Watne

Torgeir Bruun Wyller (f. 1960) er professor i geriatri ved Universitetet i Oslo, overlege ved Oslo universitetssykehus, og har etablert Oslo Delirium Research Group.

Ingen oppgitte interessekonflikter.

Leiv Otto Watne (f. 1977) er postdoktorstipendiat og under spesialisering $\mathrm{i}$ indremedisin og geriatri ved Oslo universitetssykehus, og leder av Oslo Delirium Research Group.

Ingen oppgitte interessekonflikter. 
Litteratur

1. Reiakvam KK, Astor MC, Kittang BR. En kvinne i 70-årene med rask forverring av kognitiv funksjon. Tidsskr Nor Legeforen 2016; 136: 1096-8.

2. American Psychiatric Association. Diagnostic and Statistical Manual of Mental Disorders (DSM-5). https://www.psychiatry.org/psychiatrists/practice/dsm/ dsm-5 (20.7.2016).

3. Neerland BE, Watne LO, Wyller TB. Delirium hos eldre pasienter. Tidsskr Nor Legeforen 2013; 133: 1596-600.

4. Davis DH, Muniz Terrera G, Keage $\mathrm{H}$ et al. Delirium is a strong risk factor for dementia in the oldest-old: a population-based cohort study. Brain 2012; 135: 2809-16.

5. Pandharipande PP, Girard TD, Jackson JC et al; BRAIN-ICU Study Investigators. Long-term cognitive impairment after critical illness. N Engl J Med 2013; 369 : $1306-16$.

\section{K.K. Reiakvam \& B.R. Kittang svarer:}

Vi takker Wyller \& Watne for utfordrende kritiske kommentarer til vår artikkel (1), som gir oss anledning til å utdype viktige punkter i kasuistikken.

Vi er enige i det de skriver om viktigheten av delirium og utredningen av dette: raskt, grundig og på egnet nivå i helsetjenesten. Hovedinnvendingen mot oss er at vi ikke har gitt pasienten diagnosen delirium, og dermed vist manglende kunnskap om DSMs diagnosekriterier. Hvilken feil er det Wyller \& Watne mener vi har gjort? Vi har ikke glemt å tenke på diagnosen. Vi har vurdert og forkastet den, selv om vi ser at betegnelsen subsyndromalt delirium kanskje kunne vært anvendt (2). Vurderingen førte ikke til forsinket utredning eller feilbehandling. Ifølge Wyller \& Watne har vi feilklassifisert et klinisk bilde: Gjennom lesing av artikkelen og særlig vektlegging av uttrykkene «passiv», «likegyldig» og «fjern i blikket», finner de alle diagnostiske kriterier for delirium oppfylt. Men mens vi som klinikere har observert og vurdert en sykdomstilstand av en viss varighet, har de vurdert vår skriftlige gjengivelse av denne i kasuistikkform.

Mye kunne skrives om et krevende utvelgelsesarbeid under utformingen av artikkelen. La oss heller kortfattet prøve å gjengi litt mer av det kliniske forløpet: Da pasienten ankom sykehjemmet (dag 1) ble bevisstheten, som angitt i artikkelen, beskrevet som «klar», og frem til den akutte forverringen som førte til sykehusinnleggelse var hun klinisk stabil og uten tegn til endringer i bevisstheten eller fluktuerende symptomer. Da hun dagen etter innleggelse i sykehus ble skåret med Confusion Assessment Method kunne undersøkeren krysse «ja» på første spørsmål (akutt endring i mental tilstand), ellers «nei» på alle andre spørsmål (dvs. ikke vekslende forløp, uoppmerksomhet, desorganisert tankegang eller endret bevissthetsnivå). Ved gjentatte samtaler var hun rolig, samarbeidende, lyttende, og hun ga hele tiden blikkontakt, samtidig som blikket var påfallende «fjernt». Hun svarte på en måte som virket gjennomtenkt, men ordfattig, ikke typisk for fremre afasi. Hukommelsessvikten besto av en lettere anterograd amnesi, men atskillig mer uttalt retrograd amnesi, inkludert amnesi for personlige data. Beskrivelsen av pasienten som passiv og likegyldig kunne ha vært nyansert med hvordan hun paradoksalt nok samtidig fremsto som «åpen» og «tilbaketrukket». Hun var ikke psykomotorisk påvirket og viste ikke tegn til hyperaktivt eller hypoaktivt delirium. Tilstanden vedvarte, i jevnt avtakende grad under sykehusoppholdet.

Vi har aldri sett maken til dette sykdomsbildet, og flere andre sjeldne tilstander ble vurdert og utredet. Å beskrive slike atypiske kliniske forløp i den knappe form som en kasuistikk i Tidsskriftet krever, er utfordrende.

At artikkelen har skapt reaksjoner hos skarpe lesere, er forståelig. Men vi tror at dersom Wyller \& Watne hadde truffet denne pasienten mens hun var som sykest, så ville de opplevd hennes tilstand på en lignende måte - og muligens funnet mer treffende måter å beskrive den på.

Den aller største gleden ved arbeidet var for øvrig å bidra til at pasienten ble frisk, og uten sikre sekveler, vurdert ved våre kontakter med pasienten i ettertid.

Kyrre Kittang Reiakvam

kyrre.kittang.reiakvam@haraldsplass.no

Bård Reiakvam Kittang
Kyrre Kittang Reiakvam (f. 1975) er overlege og spesialist i indremedisin og i geriatri ved Medisinsk avdeling, Haraldsplass Diakonale Sykehus. Ingen oppgitte interessekonflikter.

Bård Reiakvam Kittang (f. 1971) er overlege, ph.d. og spesialist i indremedisin og i infeksjonssykdommer ved Avdeling for sykehjemsmedisin og Medisinsk avdeling. Haraldsplass Diakonale Sykehus.

Ingen oppgitte interessekonflikter.

\section{Litteratur}

1. Reiakvam KK, Astor MC, Kittang BR. En kvinne i 70-årene med rask forverring av kognitiv funksjon. Tidsskr Nor Legeforen 2016; 136: 1096-8.

2. Meagher D, Adamis D, Trzepacz $P$ et al. Features of subsyndromal and persistent delirium. Br J Psychiatry 2012; 200: 37-44

\section{Re: Incentiver og deltagelse i en medisinsk spørreundersøkelse}

Jeg har med interesse lest Gjøstein og medarbeideres studie (1), der de finner at å vedlegge et skrapelodd ikke øker svarprosenten ved utsendelse av spørreskjema. Jeg er imidlertid overrasket over at forfatterne i diskusjonen ikke nevner det økonomiske incentiv som er vist å virke best: cash! Forfatterne refererer til et av våre arbeider (2) der vi fant at skrapelodd ikke hadde virkning. Vi tenkte i ettertid at forklaringen kanskje kan være at mottageren i utgangspunktet blir glad for skrapeloddet, men så straks skraper det. Han vil vanligvis ikke få gevinst, og det er mulig at denne skuffelsen heller virker demotiverende enn motiverende for å fylle ut og returnere skjemaet. Forfatterne nevner ikke at vi i det samme arbeidet fant at svarprosenten økte fra 73 hos dem som hadde fătt et skrapelodd til 88 ved i stedet å legge ved en 50-kroneseddel. En Cochrane-gjennomgang (3) konkluderte at et pengebeløp er det beste av alle rapporterte incentiver. I Norge må imidlertid det vedlagte beløpet være ganske stort for å ha virkning. Vi fant i en annen studie (4) svarprosenter på 54 uten penger, 53 med én krone, 58 med ti kroner, og 74 med 50 kroner. Det kan med andre ord bli nokså kostbart, men er muligens regningssvarende om alternativet er å betale et firma for å ringe til dem som ikke har svart, slik det ble gjort i Gjøstein og medarbeideres studie. Gevinsten er en god svarprosent og derved bedre forskning.

\section{Vilhjalmur Finsen}

vilh.finsen@ntnu.no

Vilhjalmur Finsen (f. 1946) er overlege og professor ved St. Olavs hospital og Det medisinske fakultet, Norges teknisk-naturvitenskapelige universitet.

Ingen oppgitte interessekonflikter.

\section{Litteratur}

1. Gjøstein DK, Huitfeldt A, Løberg M et al. Incentiver og deltagelse i en medisinsk spørreundersøkelse. Tidsskr Nor Legeforen 2016; 136: 1082-7.

2. Finsen V, Storeheier AH. Scratch lottery tickets are a poor incentive to respond to mailed questionnaires. BMC Med Res Methodol 2006; 6: 19

3. Edwards PJ, Roberts I, Clarke MJ et al. Methods to increase response to postal and electronic questionnaires. Cochrane Database Syst Rev 2009; 3: MR000008. 4. Finsen V. Tiltag for at $\varnothing g$ ge svarprocenten ved spørgeskemaunders $\varnothing$ gelser Ugeskr Laeger 2011; 173: 39-41.

\section{D.K. Gjøstein og medarbeidere svarer:}

Finsen fremhever flere viktige poeng rundt det praktiske og kostnadsmessige ved valg av tiltak for å øke svarprosent i medisinske spørreskjemaundersøkelser. Det er uklart om skrapelodd øker svarprosenten $(1,2)$, og i vår studie fant vi ingen effekt (3). Finsen har tidligere funnet at ubetingede incentiver $\mathrm{i}$ form av kontanter synes å ha høyere effekt enn skrapelodd, men dette forutsetter at kontantbeløpets størrelse er betydelig (4). 